\title{
Analisis Hubungan Perilaku Caring dengan Tingkat Kepuasan Pelayanan Kesehatan
}

\author{
Rahmania Ambarika* ${ }^{1}$, Lingga Kusuma Wardani ${ }^{2}$ \\ ${ }^{1,2}$ Program Studi Pendidikan Ners IIK STRADA Indonesia \\ *Alamat Korespondensi: J1. Manila No.37, Tosaren, Kec. Pesantren, Kota Kediri, Jawa \\ Timur 64133 \\ Email: rahmania.ambar@gmail.com
}

Diterima: 9 Juni 2021 | Disetujui: 22 Juni 2021

\begin{abstract}
Abstrak
Latar Belakang dan Tujuan: Rendahnya perilaku caring menjadi salah satu penyebab dari ketidakpuasan pasien di unit pelayanan kesehatan. Padahal perilaku caring bagi pasien dapat memberikan banyak manfaat. Tujuan penelitian ini adalah menganalisis adanya hubungan perilaku caring dengan tingkat kepuasan pasien.

Desain Penelitian: Penelitian ini menggunakan pendekatan correlasional yang dilakukan di UPTD Puskesmas Poncokusumo Kabupaten Malang. Sample penelitian ini adalah 38 responden yang memenuhi kriteria inklusi. Teknik pengambilan sampling yang digunakan adalah purposive sampling. Pengumpulan data dengan kuesioner, selanjutnya data dianalisis dengan menggunakan uji statistik Spearman's rho.

Hasil: Sebagian besar responden menunjukkan bahwa perilaku caring adalah baik yaitu sebanyak 27 responden $(71,05 \%)$. Kepuasan menunjukkan bahwa sebagian besar responden menyatakan puas dengan pelayanan yang ada yaitu sebanyak 26 responden $(68,42 \%)$. Hasil analisis didapatkan terdapat hubungan perilaku caring dengan tingkat kepuasan pelayanan kesehatan.

Simpulan dan Implikasi: Perilaku caring akan berpengaruh terhadap kepuasan pasien. Perilaku caring yang baik akan menjadikan kepuasan pasien ke arah positif, karena pasien memiliki kepercayaan yang tinggi dalam menilai pelayanan kesehatan sehingga berdampak pada kunjungan ulang pasien, dan rasa percaya pada pelayanan hesehatan.
\end{abstract}

Kata Kunci: Caring; Kepuasan Pasien; Perilaku

Sitasi: Ambarika, R \& Wardani, L.K. (2021). Analisis hubungan perilaku caring dengan tingkat kepuasan pelayanan kesehatan. The Indonesian Journal of Health Science. 13(1), 53-60. DOI: 10.32528/ijhs.v13i1.5273

Copyright: () 2021 Ambarika, et.al. This is an open-access article distributed under the terms of the Creative Commons Attribution-NonCommercial 4.0 International License, which permits unrestricted use, distribution, and reproduction in any medium, provided the original author and source are credited.

Diterbitkan Oleh: Universitas Muhammadiyah Jember

ISSN (Print): 2087-5053

ISSN (Online): 2476-9614

DOI : 10.32528/ijhs.v13i1.5273 


\begin{abstract}
Background and Aim: The low caring behavior is one of the cause of patient dissatisfactions. Whereas caring behavior for patients can provide many benefits. The purpose of this study was to analyze the relationship between caring behavior and the level of patient satisfaction.

Methods: The design of this study using correlational approach. This research was conducted at the UPTD Poncokusumo Public Health Center, Malang Regency. The sample of this study was 38 respondents who met the inclusion criteria. The sampling technique used was purposive sampling. Collecting data with a questionnaire, then the data was analyzed using the Spearman's rho statistical test.

Results: Most of the respondents indicated that the caring behavior was good, as many as 27 respondents (71.05\%). Satisfaction showed that most of the respondents stated that they were satisfied with the existing services, namely as many as 26 respondents (68.42\%). The results of the analysis showed that there was a relationship between caring behavior and the level of satisfaction of health services.

Conclusion: Caring behavior will affect patient satisfaction. Good caring behavior will make patient satisfaction in a positive direction, because patients have high confidence in assessing health services so that it has an impact on patient repeat visits, and trust in health services.
\end{abstract}

Keywords: Behavior; Caring; Patient Satisfaction

\section{PENDAHULUAN}

Pelayanan kesehatan yang bermutu adalah pelayanan kesehatan yang dapat memuaskan setiap pemakai jasa layanan. Tenaga kesehatan memberikan pelayanan kesehatan yang diwujudkan dengan sikap caring salah satunya sikap peduli, simpati, bertanggung jawab dan ramah dalam layanan kesehatan. Perilaku caring berperan dalam menentukan kepuasan pasien. Kepuasan pasien merupakan satu elemen yang penting dalam mengevaluasi kualitas layanan dengan mengukur sejauh mana respon pasien setelah menerima jasa (Pohan I, 2013).

Kepuasan pasien merupakan faktor yang sangat penting untuk mengevaluasi mutu pelayanan kesehatan dan perilaku caring adalah salah satu aspek yang berhubungan dengan pelayanan kesehatan, karena caring mencakup hubungan antar manusia dan berpengaruh terhadap mutu pelayanan dan kepuasan pasien (Perry \& Potter, 2009).

Dampak perilaku caring bagi pasien adalah meningkatkan hubungan saling percaya, meningkatkan penyembuhan fisik, keamanan, memiliki banyak energi, biaya perawatan lebih rendah, serta menimbulkan perasaan lebih nyaman dan puas (Watson, 2007). Penelitian Agustin (2002) serta penelitian Palese., et al (2011) menyatakan bahwa perilaku caring dapat memberikan kontribusi terhadap kepuasan pasien.

Masih banyak tenaga kesehatan yang kehilangan makna caring dalam pekerjaannya sehingga hari-harinya sibuk dengan peralatan medis untuk pengobatan pasien dan tindakan keperawatan. Hasil penelitian Agustin (2002) dan Juliani (2009) menemukan bahwa pelaksanaan perilaku caring 
perawat masih rendah. Hal ini menunjukkan bahwa perilaku caring masih belum sepenuhnya diterapkan dalam keperawatan.

Rendahnya perilaku caring menjadi salah satu penyebab dari ketidakpuasan pasien. Masalah emosional pasien dapat terjadi karena rasa sakit akut yang dirasakan, belum mengetahui diagnosis penyakit, dan belum mendapatkan terapi. Dalam keadaan seperti ini pasien sangat membutuhkan perhatian, kepekaan, dan sikap peduli dari perawat untuk menanggapi keluhannya, sehingga perilaku caring sangat dibutuhkan dalam pelayanan kesehatan (Suryani, 2010).

Pelayanan kesehatan yang berkualitas tidak hanya ditunjukkan oleh pengetahuan tentang penyakit pasien, keterampilan melakukan tindakan atau keterampilan mengoperasikan alat-alat kesehatan (Izumi, et al 2010). Kualitas pelayanan keperawatan ditentukan oleh empat domain yaitu kompetisi, caring, profesionalisme dan demeanor atau cara bertindak. Akan tetapi kenyataannya permasalahan dan kendala utama pada pelaksanaan di lapangan banyak tenaga kesehatan kurang care terhadap pasien. Kontak antara tenaga kesehatan dengan pasien dibatasi oleh waktu sehingga diselesaikan dengan terburu-buru. Keterbatasan kontak tersebut berarti bahwa asuhan psikologis pasien kurang. Sedangkan setiap pasien dan keluarga mengharapkan kualitas hubungan individu yang baik dari perawat (Rahayu, 2006).

Hasil penelitian Agustin (2002) kepuasan pasien di RS dr. Mohammad Hoesin Palembang hanya 48,8\%. Berdasarkan hasil penelitian Hadi (2019) perilaku caring perawat berhubungan dengan tingkat kepuasan pasien di ruang rawat inap rumah sakit. Perubahan leadership dalam profesi keperawatan terus dikembangkan, diharapkan dapat diaplikasikan secara nyata, semakin berkembang, semakin diakui dan dapat menunjukkan kinerja yang profesional dalam memberikan pelayanan kesehatan

Berdasarkan permasalahan tersebut, tujuan penelitian melakukan analisis kaitan antara kepuasan pasien ditinjau dari caring dalam memberikan pelayanan kesehatan.

\section{METODE PENELITIAN}

Rancangan penelitian analitik korelasional dengan pendekatan cross sectional. Populasi seluruh pasien dewasa rawat inap di UPTD Puskesmas Poncokusumo Kabupaten Malang pada bulan September sampai November 2020 sebanyak 153 pasien dengan purposive sampling didapatkan jumlah sampel 38 pasien.

Sampel pada penelitian ini ditentukan berdasarkan kriteria inklusi. meliputi: 1) Pasien yang bersedia untuk menjadi responden ; 2) Pasien yang sedang opname minimal 3 hari ; 3) Pasien yang bisa diajak komunikasi dengan baik ; 4) Pasien yang sudah dewasa (20-60 tahun).

Instrumen yang digunakan adalah kuesioner. Kuesioner perilaku caring perawat adalah kuesioner baku dari Nursalam (2015) yang terdiri dari 23 pertanyaan. Sedangkan kuesioner kepuasan adalah kuesioner baku dari Nursalam (2007) yang terdiri dari 25 pertanyaan. Analisis data menggunakan uji statistik Spearman's rho.

\section{HASIL}

Karakteristik jenis kelamin responden menunjukkan sebagian besar adalah pasien perempuan dengan jumlah 23 pasien (61\%) (Gambar 1). 
Karaktersitik usia diketahui setengahnya usia responden antara 4660 tahun yaitu sebanyak 18 orang (47\%) (Gambar 2). Sedangkan untuk tingkat pendidikan hampir setengah responden memiliki pendidikan PT yaitu sebanyak 16 orang $(42 \%)$ (Gambar 3).

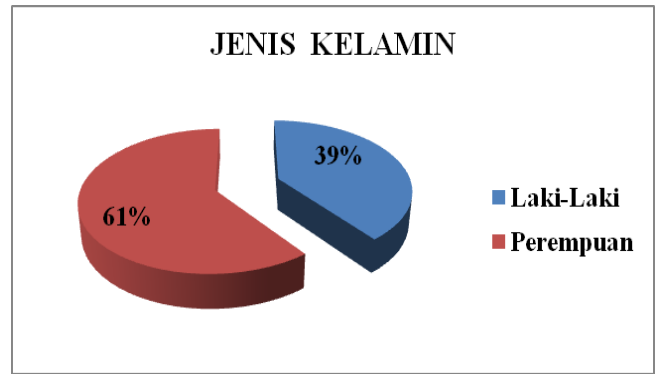

Gambar 1: Karakteristik responden berdasarkan jenis kelamin

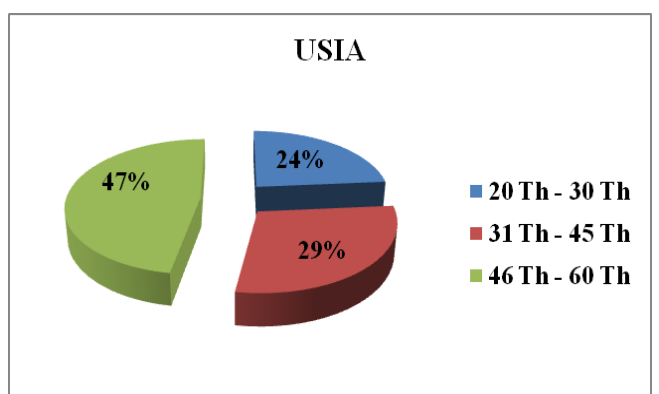

Gambar 2: Karakteristik responden berdasarkan usia

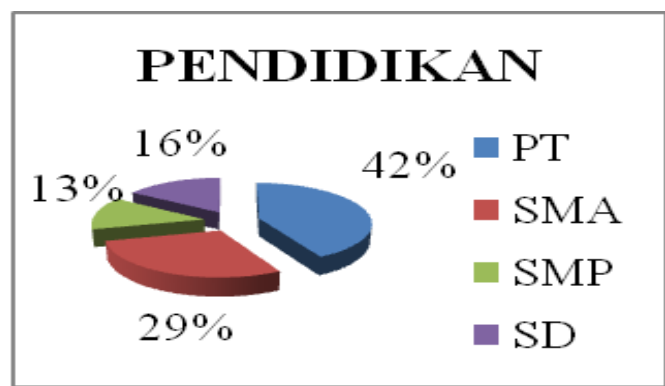

Gambar 3: Karakteristik responden berdasarkan tingkat pendidikan

Perilaku caring perawat mayoritas baik yaitu sebanyak 27 responden (71,05\%) (Tabel 1). Sedangkan kepuasan pasien sebagian besar merasa puas yaitu sebanyak 26 responden $(68,42 \%)$ (Tabel 2). Dari uji statitik Spearman's Rho dengan $\alpha=$ 0,05 didapatkan $p$ value $0,0005<0,05$. Dengan demikian ada hubungan yang signifikan antara perilaku caring dengan tingkat kepuasan pelayanan kesehatan dengan kekuatan korelasi sangat kuat dan arah positif, artinya semakin baik perilaku caring perawat maka pasien akan semakin puas dengan pelayanan kesehatan.

Tabel 1. Karakteristik variabel perilaku caring

\begin{tabular}{ccc}
\hline Caring & $\sum$ & \% \\
\hline Baik & 27 & 71.05 \\
Cukup & 10 & 26.32 \\
Kurang & 1 & 2.63 \\
\hline Total & 38 & 100 \\
\hline
\end{tabular}

Tabel 2. Karakteristik variabel kepuasan pasien

\begin{tabular}{ccc}
\hline Kepuasan & $\sum$ & \% \\
\hline Puas & 26 & 68.42 \\
Cukup & 10 & 26.32 \\
Kurang & 2 & 5.26 \\
\hline Total & 38 & 100 \\
\hline
\end{tabular}

Tabel 3: Hubungan perilaku caring dengan kepuasan pelayanan kesehatan

\begin{tabular}{ccc}
\hline Variabel & $P$ value & $r$ \\
\hline $\begin{array}{c}\text { Perilaku } \\
\text { caring } \\
\text { dengan } \\
\text { kepuasan }\end{array}$ & 0.000 & 0.838 \\
\hline
\end{tabular}

\section{PEMBAHASAN}

Hasil penelitian diketahui sebagian besar perilaku caring perawat adalah baik dan hampir setengahnya responden menyatakan bahwa perilaku caring kategori cukup.

Menurut Cinn (2010), perilaku caring adalah be ourselves yaitu sebagai manusia harus jujur, dapat dipercaya, tidak tergantung pada orang lain. Artinya bahwa setiap orang harus menjadi diri sendiri dan mandiri. 
Clarity, keinginan untuk terbuka dengan orang lain. Respect yaitu selalu menghargai orang lain. Belajar menerima dan memahami orang lain dan belajar menjadi makhluk sosial. Separatenes dalam caring tidak berarti terbawa dalam depresi atau ketakutan orang lain. Tatap dalam kondisi waspada dengan mempersiapkan diri secara fisik dan psikologi. Freedom adalah memberi kebebasan pada orang lain untuk mengekspresikan perasaannya. Emphaty yaitu dengan memahami perasaan pasien tetapi dirinya tidak hanyut oleh perasaan tersebut baik secara emosional maupun fisik. Communication yaitu komunikasi verbal dan non verbal harus menunjukkan keselarasan. Evaluation yaitu dilakukan bersamasama perawat dan pasien.

Perawat dituntut untuk memberikan asuhan keperawatan kepada pasien dan keluarganya khususnya memberikan penjelasan kepada mereka tentang tindakan yang akan dilakukan dengan sejelas-jelasnya tanpa memandang status sosialnya. Ini kadangkala sulit dilakukan karena banyaknya tugas perawat yang harus diselesaikan selain sebagai perawat juga sebagai administrasi pasien.

Berdasarkan hasil penelitian teridentifikasi perilaku caring perawat tergolong baik $(71,05 \%)$, sehingga dapat dilihat ada potensi untuk pelaksanaan pelayanan keperawatan yang semakin baik juga. Hasil penelitian menunjukkan bahwa dalam memberikan asuhan keperawatan sebagian besar perawat telah memperkenalkan diri dan menjelaskan perannya kepada pasien, hanya saja perawat jarang menyediakan waktu khusus untuk mengkaji secara mendalam masalah yang dialami pasien dan masih ada yang kurang memberikan perhatian penuh kepada pasien, perawat jarang mendiskusikan kondisi pasien dan memberikan umpan balik pada pasien. Hal ini perlu menjadi perhatian unit keperawatan rumah sakit untuk mempertahankan perilaku caring yang baik. Perawat yang berperilaku caring terhadap pasien berarti perawat tersebut sudah mampu memberikan pelayanan yang baik kepada pasien. Sikap caring berarti perawat bersikap empati, memberi dukungan, simpati serta perlindungan kepada pasien. Dengan menunjukkan sikap caring maka dapat memberikan pengalaman yang baik untuk pasien.

Pendapat ini didukung oleh Wolf, Miller \& Devine (2010) yang menyatakan bahwa kinerja staf perawat termasuk perilaku caring dapat memberikan kontribusi besar terhadap kualitas pengalaman pasien selama dilakukan perawatan. Semakin baik perilaku caring perawat dalam memberikan pelayanan asuhan keperawatan, pasien atau keluarga semakin senang dalam menerima pelayanan, berarti hubungan terapeutik perawat-klien semakin terbina. Berdasarkan hasil wawancara dengan responden ditemukan bahwa merasa puas dengan perawat yang ramah, mudah senyum, sopan dan memberi perhatian.

Hasil penelitian menunjukkan bahwa sebagian besar responden menyatakan puas dengan pelayanan yang ada. Berdasarkan jenis kelamin, responden terbanyak adalah yang berjenis kelamin perempuan. Seorang laki-laki yang menjadi kepala keluarga cenderung melindungi atau intervensi dan memberikan rasa aman bagi keluarganya. Pria juga lebih mempengaruhi wanita dalam memberikan pendapat atau pertimbangan untuk melakukan sesuatu (Notoatmojo, 1985). 
Berdasarkan usia responden, penelitian ini termasuk ke dalam kelompok usia dewasa pertengahan yang secara psikologis telah mencapai perkembangan kognitif yang optimal (Potter dan Perry, 2010). Peneliti berpendapat bahwa responden yang berusia dewasa, memiliki kemampuan untuk memberikan penilaian secara objektif terhadap pengalaman mendapatkan pelayanan selama pasien berada di puskesmas.

Berdasarkan tingkat pendidikan, Agustin (2002) menyatakan bahwa individu yang memiliki pendidikan tinggi umumnya telah mendapat banyak informasi tentang pelayanan kesehatan serta cenderung memiliki pengalaman terhadap pelayanan kesehatan yang lebih banyak sehingga mereka memiliki harapan yang tinggi terhadap pelayanan kesehatan. Notoatmojo (2005) menyatakan bahwa tingkat pendidikan merupakan salah satu faktor yang mempengaruhi harapan dan persepsi pasien terhadap pelayanan kesehatan. Siagian (2000) menyatakan bahwa semakin tinggi tingkat pendidikan seseorang semakin besar pula keinginan dan harapannya, maka tingkat pendidikan yang tinggi akan cenderung menyebabkan tingkat kepuasan yang rendah sehingga diperlukan pelayanan yang berkualitas tinggi untuk mendapatkan kepuasan.

Sebagai penyedia jasa Rumah Sakit harus memenuhi semua apa yang menjadi kepuasan pelanggan dalam hal ini pasien dan keluarga bahkan sampai dengan pengunjung yang lain. Seorang perawat yang dalam waktu 24 jam berada dengan pasien harus melakukan semua kegiatan yang dibutuhkan pasien, ini merupakan suatu kemampuan untuk berdedikasi bagi orang lain, pengawasan dengan waspada, perasaan empati pada orang lain dan perasaan cinta atau

DOI : 10.32528/ijhs.v13i1.5273 menyayangi. Bila sudah terjadi hubungan saling percaya antara pasien dan perawat maka kepuasan akan tercapai. Sehingga tercipta pelayanan prima bagi rumah sakit tersebut.

Hasil penelitian menunjukkan bahwa ada hubungan yang signifikan antara perilaku caring dengan tingkat kepuasan pasien, namun masih terdapat $5,26 \%$ yang kurang puas dengan perilaku caring. Hal ini dapat disebabkan oleh pengalaman dan faktor demografi responden dalam menerima pelayanan. Pernyataan ini didukung teori yang dikemukakan oleh Singgih (2012) bahwa seorang pasien yang pada masa sehat terbiasa hidup dengan pelayanan yang sepenuhnya dipusatkan pada pemuasan semua keinginan, tentu sewaktu mendapat perawatan akan menuntut perlakuan yang sesuai dengan yang diperolehnya dalam hidup sehari-hari. Kepuasan pasien dapat diukur dengan indikatorindikator: Kepuasan terhadap akses layanan, mutu layanan kesehatan dan kepuasan terhadap proses layanan kesehatan termasuk hubungan antar manusia.

Pada penelitian ini terdapat $2,63 \%$ yang mempunyai persepsi kurang baik tentang perilaku caring (kurang caring) namun merasa puas. Hal ini dapat disebabkan hubungan yang baik perawat dengan pesien atau keluarga. Pernyataan ini didukung teori bahwa tenaga kesehatan yang dapat meyakinkan pasien/keluarga akan memperoleh kepercayaan dari pasien, sehingga secara tidak langsung dapat membantu membentuk sikap positif pasien terhadap perawat (Singgih et.al., 2012). Ada orang sakit yang ingin selalu diperhatikan dan menarik perhatian perawat, ada pula pasien yang sungkan dan segan untuk memanggil dan meminta bantuan perawat (Singgih et.al, 2012). 
Jones (2008) menjelaskan bahwa untuk menciptakan sebuah kepercayaan pasien adalah dengan menciptakan waktu bersama dengan pasien. Tenaga kesehatan yang berhasil adalah membangun kepercayaan akan membuat pekerjaan perawat menjadi lebih mudah karena pasien yang sudah percaya akan menerima seluruh kegiatan yang dilakukan dalam memberikan pelayanan kesehatan untuk kepuasan pasien.

Hubungan perilaku caring menunjukkan bahwa terdapat kecenderungan semakin baik perilaku caring maka terjadi kepuasan yang tinggi. Perilaku yang kurang caring akan mempengaruhi kepuasan pasien yang rendah. Hubungan tersebut memberikan penjelasan bahwa sikap caring mempengaruhi kualitas asuhan yang pada akhirnya dapat mempengaruhi kepuasan pasien di mana apabila dalam memberikan layanan bersikap tidak caring kepada pasien maka pasien tentunya akan merasa tidak senang dan akhirnya bisa melakukan komplain dan bisa juga akan pindah ke layanan kesehatan yang lain sehingga hal tersebut akan membuat citra tempat pelayanan kesehatan tersebut menjadi kurang baik. Dampak pasien yang puas yaitu kembali berkunjung lagi atau memakai jasa layanan lagi, membicarakan kepada orang lain tentang kenyamanan yang diterima.

Perilaku caring sangat mempengaruhi kepuasan pasien, apabila pelayanan yang diberikan sudah sesuai dengan kebutuhan pasien dan diberikan dengan cara yang ramah pada waktu mereka dirawat sesuai sumber daya yang dimiliki, maka pasien akan merasakan kepuasan yang tinggi. Hal ini didukung teori Pohan (2007) yang menyatakan bahwa kualitas pelayanan kesehatan memiliki pengaruh terhadap frekuensi tingkat kepuasan pasien. Semakin baik kualitas pelayanan kesehatan maka semakin baik pula frekuensi tingkat kepuasan pasien.

\section{SIMPULAN}

Perilaku caring sebagian besar dalam kategori baik dan untuk tingkat kepuasan pelayanan sebagian besar dalam kategori puas. Dari hasil ini disimpulkan bahwa semakin baik perilaku caring perawat maka pasien akan semakin puas dengan pelayanan kesehatan.

\section{SARAN}

Pasien hendaknya memanfaatkan sarana kotak saran yang ada di rumah sakit, sebagai penyampaian kritik dan saran bagi pelayanan kesehatan agar dijadikan evaluasi untuk menjadikan pelayanan yang lebih baik dan optimal. Sedangkan untuk tenaga kesehatan hendaknya menerapkan perilaku caring. Bagi Puskesmas diharapkan memasukkan perilaku caring sebagai standar dalam penilaian kinerja bagi perawat, meningkatkan pelaksanaan perilaku caring, dengan cara memberikan penghargaan kepada tenaga kesehatan yang telah menerapkan perilaku caring dalam melakukan pelayanan terhadap pasien, serta survei kepuasan pasien perlu dilakukan secaran berkala, karena kepuasan pasien merupakan alat ukur untuk intropeksi diri personel pelayanan keperawatan dan sebagai salah satu acuan untuk meningkatkan mutu layanan kesehatan .

\section{DAFTAR PUSTAKA}

Agustin, I (2002). Perilaku caring perawat dan hubungannya dengan kepuasan klien di Instalasi Rawat Inap Bedah 
Dewasa RS dr. Muhammad Hoesin Palembang tahun 2002. (Tesis). Universitas Indonesia, Depok.

Asrini, Yuli (2012). Hubungan antara persepsi pasien tentang perilaku caring perawat dengan tingkat kepuasan pasien di instalsi rawat inap pavilion Garuda B RSUP dr Karyadi semarang

Chinn, P.L. (2010). Anthologi on Caring. New York: National League for Nursing Press.

Hadi S (2019). Hubungan perilaku caring perawat dengan kepuasan pasien di ruang rawat inap. Jurnal Ilmu Keperawatan dan Kebidanan Vol.10 No.1 (2019) 243-247

Izumi, S., Baggs, J.G., Knafi, K.A (2010). Quality nursing care for hospitalized patients with advanced illnes: Concept development. Research in Nursing \& Health.

Jones (2008). Perception of nurses caring behaviors by trauma patient. Journal of advance nursing vol 2 page 645 - 658

Juliani, Enni. (2009). Hubungan beban kerja perawat pelaksana dengan pelaksanaan perilaku caringmenurut persepsi klien di Irna Lantai Jantung RS Husada Jakarta. (Tesis). Program Pasca Sarjana, Fakultas Ilmu Keperawatan, Universitas Indonesia, Depok

Notoatmodjo. S. (2010). Metodologi penelitian kesehatan. Edisi revisi. Jakarta: Rineka Cipta.

Palese, et al. (2011). Surgical patient stisfaction as an outcome of nurses caring behaviors: A descriptive and correlational study in six European
Countries. Journal of Nursing

Scholarship.

Pohan, Imbalo S (2007) Jaminan mutu layanan kesehatan dasardasar pengertian dan penerapan, Jakarta: EGC

Rahayu (2006). Psikologi perkembangan: Pengantar dalam berbagai bagiannya. Yogyakarta: Gajah Mada University Press

Siagian, S. (2010). Kiat meningkatkan produktivitas kerja. Jakarta: Rineka Cipta.

Suryani. (2010). Hubungan faktor individu dan perilaku caring perawat di ruang rawat inap RSUD Kota Bandung. (Tesis) program Magister Ilmu Keperawatan FIK UI, Depok

Watson, J. (2007). Theory of human caring. Danish Clinical Nursing Journal. Available from www.uchsc.edu/nursing/carin $\mathrm{g}$

Wawan \& Dewi. (2010). Teori dan pengukuran pengetahuan, sikap dan. perilaku manusia. Yogyakarta: Nuha Medika

Wolf, Z.R, Miller, P.A, Devine, M (2010) Relathionship between nurse caring and patient satisfaction in patients undergoing invasive cardiac procedures. Journal of Nursing Scholarship. 